\title{
Beretninger om kreft - møtet med helsetjenesten
}

\begin{abstract}
Bøker som skildrer erfaringer med sykdom, såkalte patografier, vitner om at pasienters og pårørendes liv kan ta en ny og dramatisk vending på grunn av sykdommen. Vi ønsket å studere hvordan pasienter og pårørende skildrer sine erfaringer og reaksjoner på møtet med helsetjenesten i norske patografier om kreft. Vi har studert fem beretninger skrevet av pasienter eller deres pårørende. Forfatterne ønsker seg leger som har tid og evne til å kommunisere,
\end{abstract} som kjenner sykdommen og er engasjert både faglig og menneskelig. Pasienters og pårørendes fortellinger om møtet med helsetjenesten preges av deres erfaringer med helsepersonell så vel som deres innstilling til kreftsykdommen.

Artikkelen er basert på en prosjektoppgave ved Det medisinske fakultet, Universitetet i Oslo (1).

De siste tiår er det utgitt en rekke bøker, såkalte patografier, som omhandler menneskers møte med sykdom og deres erfaringer med helsetjenesten $(1-5)$. Disse kan være skrevet av pasienten selv eller av pårørende. I førstnevnte tilfelle vil det mer korrekt være snakk om «autopatografier», en parallell til begrepene «biografi» og «selvbiografi». I denne artikkelen brukes begrepet «patografi» både om bøker skrevet av pasienten og om bøker skrevet av pårørende. Patografier vitner om menneskers behov for å formidle sin historie, men forfatteren kan også ha et ønske om å hjelpe andre gjennom å fortelle om sine egne opplevelser med sykdom. Sannsynligvis er det også en sammenheng mellom utviklingen av en mer selvstendig pasientrolle og fremveksten av patografier - pasientene ønsker i økende grad å ta grep om egen sykdom.

Forskere har kategorisert patografier ut fra forfatterens innstilling til sykdommen og hvilke myter og metaforer som preger beretningen $(2,6)$. Beretningene kan ha preg av kamp, restitusjon, opplevelse av kaos eller kan være en skildring av en reise i et ukjent landskap. I fortellinger med vekt på kamp fremstilles ofte sykdommen som en inntrenger som skal bekjempes. Helsetjenesten kan være alliert eller fiende i denne kampen. I beretninger om restitusjon vektlegges erfaringer med å gjenvinne helsen, hvor helsetjenesten eller alternative behandlere kan bistå som hjelpere. I fortellinger preget av opplevelse av kaos kan sykdommen trekke ut i det uendelige uten utsikter til helbredelse - eller det kan mangle forsonende innsikt hos fortelleren. Helsetjenesten kan være kilde til frustrasjon hvis den oppleves som kaotisk og ukoordinert. Noen beretninger omtaler erfaringene med sykdom som en reise hvor personlig utvikling og innsikt står sentralt. Patografier formidler reaksjoner og erfaringer som også kan forstås innenfor et kriseteoretisk rammeverk - vi gjenkjenner elementer fra sjokk-, reaksjons-, bearbeidings- og nyorienteringsfasen (7).

«Kreft» er betegnelsen på en rekke sykdommer med ulik prognose, men ordet vekker likevel felles assosiasjoner som gjør at man kan snakke om kreft som én sykdomskategori (8). Den som får en kreftdiagnose, vil som regel erfare at livet tar en ny og dramatisk vending. Dette kan være en forklaring på at det er skrevet mange selvbiografiske bøker om temaet (5). Man befinner seg $i$ en sårbar situasjon hvor man må forholde seg til helsevesenet. Vi forventer derfor at patografier om kreft vil formidle erfaringer med helsetjenesten, hvordan den fungerer på godt og på vondt og hvordan den ideelt sett burde fungere. Vi ønsket å studere hvordan pasienter og pårørende skildrer sine erfaringer og reaksjoner i møte med helsetjenesten i norske patografier om kreft.

\section{Fem beretninger}

Via søk med ordene «kreft» og «biografi» i litteraturbasen BIBSYS og på Internett, inkludert Kreftforeningens hjemmeside, fant vi norske utgivelser innen sjangeren. Vi ønsket at et utvalg på fem bøker skulle representere variasjon når det gjaldt pasientens alder, kjønn, fortellersynsvinkel og kreftsykdom. Vi identifiserte skildringer av møter med helsepersonell og ytringer om helsetjenesten i bøkene samt undersøkte hvilken innstilling pasient eller pårørende hadde til sykdommen. Følgende utgivelser var med i utvalget:

Den siste ydmykelsen (1992) av Heidi Tuft (9) er skrevet i dagbokform og omhandler forfatterens erfaringer med å leve med brystkreft. Boken omhandler bl.a. tiden etter at det konstateres spredning ni år etter at hun først ble diagnostisert. Forfatteren formilder erfaringer av smerte, ydmykelse, ensomhet og mangel på opplevelse av mening.

Tid for å ta farvel (2005) av Jan Ove Lindøe og Ida Lindøe (10) handler om Rigmor Lindøe, som fikk diagnosen lungekreft med spredning til lever, rygg og skjelett julen 2003 og døde sommeren 2004. Første del er skrevet av pasientens ektefelle, andre del av hennes datter. De formidler erfaringer fra å være pårørende til et menneske som rammes av alvorlig sykdom.

I Tilfeldigvis meg (2005) av Maria Thommessen (11) forteller forfatteren om det å bli diagnostisert med kreft i tykktarmen. Vi får vite at hun er ernæringsfysiolog, og hun har dels en faglig innfallsvinkel til sykdommen. Thommessen forteller om hvordan hun forsoner seg med diagnosen og formidler hvor viktig det er for henne å ha en aktiv og positiv innstilling til behandling og til livet generelt.

Idas dans - en mors beretning (2005) av Gunnhild Corwin (12) er en fortelling om datterens siste 14 måneder med leukemi. Vi får et innblikk i hennes frykt, usikkerhet og ensomhet i møtet med datterens kreftsykdom. Boken gir et nært bilde av en mor som kun ønsker at hennes datter skal ha det så godt som mulig, selv når døden er uunngåelig.

I Når kreft gir kraft (2006) av Hans Olav Tungesvik (13) beretter han, etter at han er diagnostisert med prostatakreft, om et annerledes halvår der han tydeligere enn før ser verdien av å leve her og nå. Han rapporterer at han i liten grad er plaget av bivirk-

\section{Hovedbudskap}

- Beretninger om kreft preges både av innstillingen til sykdommen og erfaringer med helsepersonell

- Reaksjoner på diagnosen, erfaringen med leger, behandlingen og organisering og informasjon i helsetjenesten beskrives

- Det er nyttig for leger å identifisere hvordan pasienter og pårørende fortolker sin egen situasjon og sitt møte med helsevesenet 
ninger av behandlingen eller av sykdommen i seg selv.

Vi har valgt å organisere våre funn i kategoriene «reaksjoner på diagnosen», «erfaringer med leger», «opplevelse av behandlingen» og «organisering og informasjon», fordi disse fremsto som viktige temaer i beretningene.

\section{Reaksjoner på diagnosen}

En avgjørende hendelse i møtet mellom pasient, pårørende og helsetjenesten er formidlingen av diagnosen. Gunnhild Corwin opplever det som et sjokk å få beskjed om at det de trodde var en langvarig forkjølelse eller mononukleose, er leukemi:

«Ordet treffer meg med full kraft. Jeg vet ikke om jeg stønner eller krøker meg sammen. Det er som å få et slag, midt i magen. [...] Vantro er det aller første jeg kjenner på. Hva er det han sitter der og sier? Leukemi? Skulle min sunne, friske attenåring ha leukemi? Absurd. Dette er noe som skjer andre. Dette skjer ikke oss, vi har altfor god helse til det. Han må ha tatt feil» (12).

En uke etter at Rigmor Lindøe innlegges til utredning, får ekteparet beskjed om diagnosen. Det er julaften, og legen forteller at hun har lungekreft med spredning til lever og ryggrad. Som hos Corwin er reaksjonen sjokk, men man kan også ane spor av bitterhet overfor legen, som ikke ser ut til å være berørt i nevneverdig grad:

«Han ser ut til å være om lag 40 år gammel. Stemmen hans er nøytral og nøktern. Men bevares. Han må vel holde en profesjonell distanse til realitetene bak de ordene han formidler. På denne avdelingen må det sannsynligvis være mer vanlig å forholde seg til døden enn å forholde seg til livet. Dette er ikke nytt for han. Jeg sitter på sengekanten og holder Rigmors venstre hånd i min. Skjønner vi rekkevidden av hva som blir sagt? Jeg vet ikke helt. Det er både grotesk uvirkelig og uhyggelig virkelig på samme tid» (10).

Thommessen forteller at hun ikke klarte å ta innover seg alvoret i situasjonen da dia- gnosen ble formidlet: «Jeg gjorde mitt ytterste for å være alvorlig og ta inn over meg det han sa - vise respekt og ærbødighet. Det var likevel vanskelig å ta ham helt på alvor» (11).

Sitatet kan leses som uttrykk for motstand hos pasienten i møtet med et alvorlig budskap. Etter noe tid og etter at hun er overflyttet til et annet sykehus erkjenner hun hva det egentlig dreier seg om:

«Sakte, men sikkert gikk det opp for meg hva legen snakket om: Cancer coli. Diagnose kreft. Tykktarmskreft med spredning. Jeg ble nummen og målløs. Alt gikk plutselig i sakte film og en tåkehinne la seg over øynene. Jeg så ikke lenger legen klart» (11).

Her er det altså fire beskrivelser av hvordan sjokkfasen kan arte seg for en som får en kreftdiagnose. Senere i bøkene får vi også beskrevet reaksjonsfasen, som for de fleste fortoner seg som smertefull. Tungesvik synes å nå nyorienteringsfasen relativt raskt, mens vi ser en mer gradvis forsoning over tid hos Thommessen og Corwin. Hos Lindøe og Tuft er forløpet mer preget av bitterhet og smerte, men vi kan mot slutten av beretningene ane en viss forsoning med sykdommen.

\section{Erfaringer med leger}

Forfatterne møter mange leger, og man får inntrykk av at det er de møtene som setter spor, enten gode eller vonde, som beskrives. De ytrer seg om hvordan de mener legen ideelt sett bør være. Tuft er opptatt av god kommunikasjon mellom lege og pasient, slik at pasienten involveres i beslutninger og ikke reduseres til objekt:

«Legen må se pasienten som en ting, det vil si hans sykdom. Og det vil som nevnt lett føre til at jeg som pasient får et redusert selvbilde. [...] Det er uunngåelig, men legen kan motvirke det ved at han tar seg tid til å bekrefte meg som person. [...] Jeg er mer enn en svulst i ryggmargen. [...] Mitt ønske er at legen både skal være en fagperson og et medmenneske» (9).

Thommessen skildrer flere av sine møter med leger: Noen er gode, noen vonde og i noen er det glimt av humor. Hun møter en kvinnelig onkolog som hun føler stor tillit til, fordi hun er rolig og tar seg tid:

«[Legen] hadde et behagelig vesen og hun virket rolig. Det virket som hun raskt oppfattet at jeg fortsatt var litt satt ut etter at jeg først uka før hadde skjønt at jeg faktisk hadde kreft. Hun tok seg god tid til å forklare situasjonen, både for meg og for Hans, som var med denne gangen» (11).

Legen bruker god tid på hennes bekymring omkring det å miste håret, noe hun setter stor pris på: «Takk, doktor. Det hjalp litt.»

Et senere møte med en ny lege etter at det er oppdaget spredning, oppleves annerledes: «Det var underlig. Her kommer vi til avtalt time, har forberedt oss og sitter nær sagt som tente lys, og så møter vi en lege som verken ser på meg eller Hans, men som stirrer ned i sine egne papirer, blander spredning i lunger med lever, beklager seg over jetlag etter en lengre reise, og for øvrig bare virker opptatt av å få svar på om jeg vil være med i en klinisk studie for utprøving av et nytt medikament» (11).

Sitatet illustrerer pasientens og pårørendes skuffelse og vitner om at man forventer å møte en lege som er oppdatert om sykdommen, som bryr seg og er engasjert.

\section{Opplevelse av behandlingen}

En viktig del av oppfølgingen i helsetjenesten dreier seg om behandling. I Idas dans gis det inngående beskrivelser av behandlingen Ida făr. Hun opplever nær sagt alle lumske bivirkninger man kan tenke seg, bl.a. åpne sår i munn og svelg, sepsis, hjerneødem, utbrudd av herpes zoster og perifer nevropati: «Bivirkningene kjenner ingen grenser. Det er utrolig hva en menneskekropp kan tåle» (12). Familien har likevel sterk tro på medisinsk teknologi og at denne skal bidra til å bekjempe sykdommen. Ida får tilbakefall, men tilliten til helsetjenesten er urokkelig.

I Tid til å ta farvel fremstilles behandlingen som del av kampen mot syk-
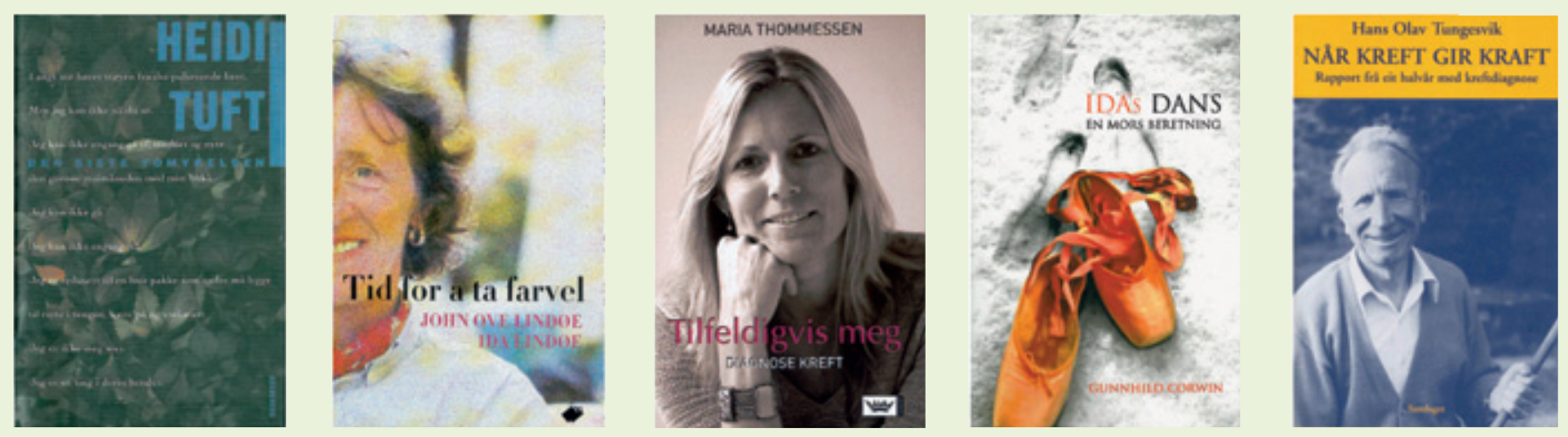

Dette er de fem bøkene som omtales i artikkelen 
dommen: «Alle disse medikamentene sammen med et program for strålebehandling er ammunisjonen vi skal bruke i første runde i krigen mot fienden. Rigmors kropp er slagmarken det skal kjempes på og kjempes om. Ikke nok med det; kamparenaen er nøye oppmerket. Rett på kroppen hennes er det tegnet inn et rutemønster med tusj som viser nøyaktig hvor strålene skal treffe. Det er ingen tvil om at vi er i krigen» (10). Kampen mot sykdommen fremstilles som en krig, og militære uttrykk preger teksten: Kroppen er en «slagmark» og strålebehandling er «ammunisjon».

I Tilfeldigvis meg kommer en annen holdning til uttrykk. Thommessen og mannen bruker mye tid på Internett til å søke etter kunnskap om ulike behandlinger. Hun advarer andre pasienter om at man på nettet kan finne informasjon man ikke er forberedt på å forholde seg til.

\section{Organisering og informasjon}

Pasientene og deres pårørende får inngående erfaringer med helsetjenesten og formulerer forslag til bedre organisering, samhandling og informasjonsflyt. Thommessen beretter for eksempel om mangelfull kommunikasjon mellom ulike instanser i helsetjenesten, og mener at god informasjon er avgjørende for pasientene:

«Et av de forholdene pasienter er minst fornøyd med på norske sykehus og i norsk helsevesen, [...] er at de ikke føler de får nok informasjon om diagnosen sin, om sykdommen, om framtidsutsiktene. For min egen del ga denne gravingen økt innsikt og forståelse av min egen situasjon» (11).

Lindøe formidler i Tid til a ta farvel frustrasjon, ettersom familien opplever at helsepersonellet ikke har tilstrekkelig oversikt og heller ikke ivaretar deres behov for informasjon:

«... det er en kraftig tilleggsbelastning å måtte utlevere sin angst, sin uro og sin avmaktsfølelse overfor stadig nye mennesker i et fremmed system. [...] Etter min beste vurdering er det et inhumant system som på denne måten sender fortvilte og urolige mennesker på rundgang mellom ulike leger alt etter hvor i behandlingssyklusen pasienten befinner seg» (10).

Det at familien ikke har noen pasientansvarlig lege å forholde seg til, gir opphav til frustrasjon på grunn av manglende kontinuitet i oppfølgingen. For pasienten var det avgjørende å skjerme seg for informasjon, slik at hun ikke skulle miste håpet. Dette ble en særlig utfordring i møtet med stadig nye leger.

\section{Diskusjon}

De fem patografiene vi har studert, vitner om at kreftpasienter og deres pårørende har ulike erfaringer med helsetjenesten. Det er kjent at psykologiske reaksjoner og personlighetsmessige forhold innvirker på pasienters og pårørendes møte med sykdommen



Pasienter med kreft forventer å møte en koordinert helsetjeneste og leger som er oppdatert om sykdommen, som bryr seg og er engasjert. Illustrasjonsfoto BSIP/GV-Press/NordicPhotos

(14). Hvordan de oppfatter helsetjenesten, er nok dels betinget $\mathrm{i}$ hvilken innstilling de har til kreftsykdommen.

Bøkene vi har studert kan klassifiseres i forhold til kategorier som kamp, restitusjon, kaos og reise. Tufts bok fremstår som en kaosfortelling, idet sykdommen er langvarig og oppfattes som meningsløs. Lidelsene hun gjennomgår, virker å være uendelige. Hun oppnår ingen innsikt som oppveier disse, og helsetjenesten blir gjenstand for mye frustrasjon. John Ove Lindøes del av Tid for å ta farvel er en beretning preget av kamp, med bruk av militære metaforer. Sykehuset oppleves og skildres som et kaotisk og inhumant system. Thommessens bok er i stor grad en beretning om restitusjon, forsoning og mestring. Corwins bok har mye av trekkene som preger restitusjonsfortellingen, selv om pasienten må gi tapt for kreften. Den kan leses som en reiseskildring hvor forfatteren formidler ny innsikt om livet som et resultat av møtet med datterens sykdom. Tungesvik skriver lite om helsetjenesten. Hans bidrag er eksempel på en reisefortelling der han formidler ny innsikt som følge av sykdommen. I to av bøkene, Tid for å ta farvel av Lindøe og Den siste ydmykelsen av Tuft, kommer det frem sterke meninger om helsetjenesten som et system de mener ikke fungerer fordi legene mangler innlevelse og helsevesenet er dårlig organisert.

Forfattere av patografier kjennetegnes ved at de i tillegg til å leve med sykdom har evner og ressurser til å skrive. Kun én av pasientene i utgivelsene vi har studert overlever kreftsykdommen. De er således neppe representative for kreftpasienter generelt, men de gir likevel innsikt i menneskelige reaksjoner ved kreftsykdom.
Patografier kan bidra til at pasientens og de pårørendes stemme blir hørt, og kjennskap til slik litteratur kan trolig gjøre leger bedre rustet til å møte den syke og vedkommendes nærmeste. Vi tror at de språklige bilder en lege introduserer, kan påvirke pasientens sykdomsoppfatning (15). Hvilke språkbilder som egner seg, vil avhenge av pasientens personlighet og sykdommens prognose og behandlingsmuligheter. Hvis det er stor sannsynlighet for at «krigen» mot kreften ikke kan vinnes, bør man kanskje være forsiktig med å omtale sykdommen som fiende og bruke militære termer om behandlingen. Har beretningen preg av kamp, restitusjon, kaos eller reise? Det kan være nyttig for leger å være seg bevisst hvilke former for «fortelling» de selv legger opp til eller befinner seg i når de møter pasienter og pårørende (16). Hvilken rolle tildeles eller inntar legen i pasientens fortelling? Er man helten, den trofaste hjelperen, en alliert eller en upålitelig fiende?

\section{Kristine Marie Mamen Vege}

kmvege@gmail.com

Det medisinske fakultet

Universitetet i Oslo

Postboks 1078 Blindern

0316 Oslo

\section{Jan C. Frich}

Institutt for helseledelse og helseøkonomi og

Institutt for allmenn- og samfunnsmedisin Universitetet i Oslo

Oppgitte interessekonflikter: Ingen 


\section{Litteratur}

1. Vege KMM. Livet med kreft - en studie av fem sykdomsbiografier. Prosjektoppgave. Oslo: Det medisinske fakultet, Universitetet i Oslo, 2008.

2. Hawkins $\mathrm{AH}$. Reconstructing illness: studies in pathography. West Lafayette, IN: Purdue University Press, 1999.

3. Hem E. Med pasientens egen penn. Tidsskr Nor Lægeforen 2001; 121: 1136-7.

4. Holmøy T, Frich JC. Beretninger fra livet med amyotrofisk lateral sklerose. Tidsskr Nor Lægeforen 2006; 126: 3297-9.

5. Häggblom K, Mattsson PO. Patografin - den sjukes egen journal. Läkartidningen 2007; 104 3548-51

6. Frank AW. The wounded storyteller: body, illness, and ethics. Chicago, IL: The University of Chicago Press, 1995

7. Weisæth L, Mehlum L, red. Mennesker, traumer og kriser. Oslo: Universitetsforlaget, 1993.

8. Sontag S. Sykdom som metafor. Oslo: Gyldendal, 1996.

9. Tuft H. Den siste ydmykelsen. Oslo: Aschehoug, 1992.

10. Lindøe JO, Lindøe I. Tid for å ta farvel. Stavanger: Wigestrand, 2005.

11. Thommessen M. Tilfeldigvis meg. Oslo: Damm, 2005

12. Corwin G. Idas dans. Lysaker: Dinamo, 2005.

13. Tungesvik HO. Når kreft gir kraft. Rapport frå eit halvår med kreftdiagnose. Oslo: Det Norske Samlaget, 2006.

14. Skaali T. Psykiske aspekter og reaksjoner ved kreftsykdom. I: Hem E, Vaglum P. Fyrand L et al, red. Pasienten og sykdommen - psykiske faktorer ved somatisk sykdom. Oslo: Gyldendal 2007: 51-8.

15. Kamps H. Pasienten som tekst - metaforer i medisinen. Tidsskr Nor Lægeforen 1999; 119: 2677-80.

16. Frich JC. Medisin som litterær virksomhet. Tidsskr Nor Lægeforen 2003; 123: 2474-6.

Manuskriptet ble mottatt 19.01. 2009 og godkjent 2.7. 2009. Medisinsk redaktør Anne Gitte Hertzberg. 